\begin{tabular}{|l|l|l||}
\hline \multicolumn{2}{|c|}{ PublisherInfo } \\
\hline \hline PublisherName & $:$ & BioMed Central \\
\hline \hline PublisherLocation & $:$ & London \\
\hline \hline PublisherImprintName & $:$ & BioMed Central \\
\hline \hline
\end{tabular}

\title{
Mitochondrial mutations
}

\begin{tabular}{|l|l|l||}
\hline \multicolumn{2}{|c||}{ ArticleInfo } \\
\hline \hline ArticleID & $:$ & 4387 \\
\hline \hline ArticleDOI & $:$ & 10.1186 /gb-spotlight-20020129-01 \\
\hline \hline ArticleCitationID & $:$ & spotlight-20020129-01 \\
\hline \hline ArticleSequenceNumber & $:$ & 53 \\
\hline \hline ArticleCategory & $:$ & Research news \\
\hline ArticleFirstPage & $:$ & 1 \\
\hline \hline ArticleLastPage & $:$ & 2 \\
\hline \hline & & RegistrationDate : 2002-1-29 \\
\hline ArticleHistory & $:$ & OnlineDate \\
\hline \hline ArticleCopyright & $:$ & BioMed Central Ltd2002-29 \\
\hline \hline ArticleGrants & $:$ & \\
\hline \hline ArticleContext & $:$ & 130593311 \\
\hline \hline
\end{tabular}




\section{Jonathan B Weitzman}

Email: jonathanweitzman@hotmail.com

Mutations in the mitochondrial genome have been associated with several genetic diseases. In an Advanced Online Publication of Nature Genetics, Robert McFarland and colleagues from the University of Newcastle-upon-Tyne describe an unusual family with a homoplasmic mitochondrial mutation (involving all copies of the mitochondrial genome; 22 January 2002, DOI:10.1038/ng819). They examined a woman who had had ten pregnancies with four different partners, all of which resulted in offspring with evidence of profound mitochondrial dysfunction. Her only surviving child has symptoms of Leigh syndrome. Analysis of mitochondrial DNA from mother and child revealed three homoplasmic mutations. One of these, C1624T, fell within the mitochondrial-tRNAVal gene. This mutation is likely to cause reduced mitochondrial protein synthesis, leading to severe respiratory-chain defects in the skeletal and cardiac muscle from the affected child. Despite the mutation, the mother is remarkably normal, with few clinical problems nor infertility. The authors conclude that homoplasmic DNA mutations may be more common than was previously thought.

\section{References}

1. Mitochondrial DNA mutations in the pathogenesis of human disease.

2. Nature Genetics, [http://www.nature.com/ng/]

3. University of Newcastle-upon-Tyne, [htpp://www.ncl.ac.uk]

4. Leigh syndrome, [http://www.ncbi.nlm.nih.gov:80/entrez/dispomim.cgi?id=256000] 